\title{
Imbibition of Water by Rockwool-Peat Container Media Amended with Hydrophilic Gel or Wetting Agent
}

\author{
George C. Elliott ${ }^{1}$ \\ Department of Plant Science, U-67, University of Connecticut, Storrs, CT 06269-4067
}

Additional index words. container capacity, effective water holding capacity, potting mix

\begin{abstract}
Water retention at effective water-holding capacity (EWHC) and container capacity (CCAP) were measured in four rockwool-peat potting media amended with a wetting agent and/or a hydrophilic gel in pots $12 \mathrm{~cm}$ tall containing $445 \mathrm{~cm}^{3}$ medium, and irrigated by capillary mat, flood-and-drain, trickle emitter, or overhead sprinkler. Water retention was measured by weighing. Irrigation was continued until EWHC (i.e., net water retention when no weight increase could be obtained by further irrigation) was reached. CCAP (i.e., net water retention following saturation and free drainage) was measured at the end of each experiment. Irrigation method and medium amendments significantly affected EWHC. Rank order of irrigation treatments was sprinkler $\geq$ trickle $>$ flood and drain $\geq$ mat. Hydrophilic gel increased both EWHC and CCAP, while the wetting agent increased EWHC but decreased or had no effect on CCAP. Significant interactions of gel and wetting agent were observed in some media. EWHC was less than CCAP, and EWHC was better correlated with CCAP with trickle emitter and overhead sprinkler irrigation than with capillary mat and flood-and-drain irrigation.
\end{abstract}

Water retention by container media is an important factor in irrigation management of potted plants. Container capacity, the amount of water retained by a given medium in a given container after saturation and free drainage (White and Mastalerz, 1966), is frequently used to describe the water-holding capacity of container media. An empirical model has been developed to predict equilibrium water-holding capacity based on container geometry and media moisture retention curves (Milks et al., 1989a, 1989b, 1989c). Equilibrium water-holding capacity has been equated with CCAP (Fonteno and Nelson, 1990). However, I am not aware of any data comparing predicted equilibrium water-holding capacity with measured CCAP.

Water retention in media may be influenced by amendments such as hydrophilic gels or wetting agents (Bilderbeck, 1987). Although reported effects of hydrophilic gels are not consistent (Bowman et al., 1990; Wang and Boogher, 1987), they have been shown in some instances to increase water-holding capacity of potting media. Wetting agents are routinely incorporated in sphagnum peat-based potting media (Nelson, 1991), but little detailed information is available regarding their effect on imbibition and water retention (Airhart et al., 1978). Preliminary observations (Blodgett and Elliott, unpublished data) indicated that in peat-vermiculite-perlite and peat-bark-perlite media, incorporation of a wetting agent increased EWHC but decreased CCAP in subirrigated media. Gel alone had no influence on EWHC, but the combination of gel and wetting agent produced higher EWHC than wetting agent alone. CCAP was greater than EWHC in all media-gel-wetting agent combinations.

Very limited information is available regarding the moisture

Received for publication 6 May 1991. Accepted for publication 18 Mar. 1992 Scientific contribution no. 1381 of the Storm Agricultural Experiment Station. Univ. of Connecticut. This work was supported: in part, with a grant from the Univ. of Connecticut Research Foundation. I thank Aquatrols, Pennsauken, N.J., and Partek North America, Englewood, Colo., for material and financial support. Mention of trademark or proprietary product names is intended only for exact description and should not be taken to imply approval to the exclusion of other products that may be suitable. The cost of publishing this paper was defrayed in part by the payment of page charges. Under postal regulations, this paper therefore must be hereby marked advertisement solely to indicate this fact.

${ }^{1}$ Assistant Professor. retention characteristics of media composed of sphagnum peat and rockwool. Simulated moisture retention curves for nongranulated rockwool and a medium containing rockwool and predicted CCAP of multicomponent blends containing rockwool were presented by Fonteno and Nelson (1990), but no in situ measurements were presented.

The objectives of this study were to 1 ) determine the influence of irrigation method, a wetting agent, and a hydrophilic gel on EWHC and CCAP in soilless media composed of sphagnum peat and rockwool; and 2) investigate the relationship between CCAP and EWHC and the influence of irrigation method, a wetting agent, and a hydrophilic gel on that relationship.

\section{Materials and Methods}

Base media composed of Canadian sphagnum peat and medium-sized, granulated, hydrophobic or hydrophilic rockwool (Pargro, Peachtree City, Ga.) in ratios of 2 peat : 1 rockwool or 1 peat : 1 rockwool (v/v) were mixed from air-dried ingredients. Water content was determined gravimetrically as the difference between air dry and oven dry (90C for $24 \mathrm{~h}$ ). Media amended with a granular wetting agent and/or a hydrophilic gel were remixed from the base media. The wetting agent (AquaGro G) was incorporated at $0.6 \mathrm{~g} \cdot \mathrm{dm}^{-3}$, and the hydrophilic gel (Supersorb C) was incorporated at $0.9 \mathrm{~g} \cdot \mathrm{dm}^{-3}$ (both products of Aquatrols, Pennsauken, N.J.).

Pots measuring $12 \mathrm{~cm}$ inside height, $7.8 \mathrm{~cm}$ top inside diameter, and $445 \mathrm{~cm}^{3}$ total volume were loose-filled to the brim with medium. No packing pressure was applied, but the side of the pot was tapped lightly as the medium was added, and further settling occurred as the result of handling. The medium was initially wetted with four successive $30-\mathrm{ml}$ applications of water with an overhead sprinkler from a precision manual dispensing pump.

After initial wetting, pots were randomly assigned to irrigation treatments. Overhead sprinkler applications comprising three successive 25-ml applications with a precision manual dispensing pump at a rate of $10 \mathrm{ml} \cdot \mathrm{s}^{-1}$ were made five to seven times

Abbreviations: CCAP, container capacity; EWHC, effective water-holding capacity. 
Table 1. CCAP and EWHC in a medium composed of 2 sphagnum peat : 1 hydrophilic, granulated, medium-sized rockwool (v/v), amended as indicated with a hydrophilic gel or a granulated wetting agent. Each datum is the mean and SD of three observations.
Table 2. CCAP and EWHC in a medium composed of 2 sphagnum peat : 1 hydrophobic, granulated, medium-sized rockwool (v/v), amended as indicated with a hydrophilic gel or a granulated wetting agent. Each datum is the mean and SD of three observations.

\begin{tabular}{|c|c|c|c|c|}
\hline \multirow[b]{2}{*}{ Irrigation } & \multirow[b]{2}{*}{ Gel } & \multirow{2}{*}{$\begin{array}{c}\text { Wetting } \\
\text { agent }\end{array}$} & \multicolumn{2}{|c|}{$\begin{array}{c}\text { Water retention } \\
\left(\mathrm{g} \mathrm{H}_{2} \mathrm{O} / \text { pot }\right)\end{array}$} \\
\hline & & & CCAP & EWHC \\
\hline \multirow[t]{4}{*}{ Overhead sprinkler } & - & - & $283 \pm 12.2$ & $234 \pm 10.9$ \\
\hline & - & + & $277 \pm 1.7$ & $237 \pm 2.7$ \\
\hline & + & - & $352 \pm 10.6$ & $325 \pm 11.1$ \\
\hline & + & + & $355 \pm 2.1$ & $338 \pm 3.8$ \\
\hline \multirow[t]{4}{*}{ Trickle emitter } & - & - & $275 \pm 1.4$ & $241 \pm 2.2$ \\
\hline & - & + & $269 \pm 2.8$ & $242 \pm 5.5$ \\
\hline & + & - & $340 \pm 2.8$ & $324 \pm 2.5$ \\
\hline & + & + & $340 \pm 9.3$ & $326 \pm 7.4$ \\
\hline \multirow[t]{4}{*}{ Flood and drain } & - & - & $288 \pm 4.8$ & $220 \pm 1.6$ \\
\hline & - & + & $277 \pm 3.6$ & $220 \pm 5.6$ \\
\hline & + & - & $342 \pm 3.0$ & $263 \pm 4.2$ \\
\hline & + & + & $326 \pm 2.5$ & $266 \pm 3.5$ \\
\hline \multirow[t]{4}{*}{ Capillary mat } & - & - & $288 \pm 1.9$ & $173 \pm 4.3$ \\
\hline & - & + & $273 \pm 0.3$ & $179 \pm 2.3$ \\
\hline & + & - & $344 \pm 4.5$ & $220 \pm 5.4$ \\
\hline & + & + & $330 \pm 7.0$ & $233 \pm 8.2$ \\
\hline \multicolumn{5}{|l|}{ Analysis of variance } \\
\hline \multicolumn{3}{|l|}{ Source } & \multicolumn{2}{|c|}{$P>\mathrm{F}$} \\
\hline \multicolumn{2}{|l|}{ Irrigation (Irri.) } & & 0.0004 & 0.0001 \\
\hline \multicolumn{2}{|l|}{$\mathrm{Gel}$} & & 0.0001 & 0.0001 \\
\hline \multicolumn{2}{|l|}{ Wetting agent } & & 0.0001 & 0.081 \\
\hline \multicolumn{2}{|l|}{ Irri. $\times$ gel } & & 0.0001 & 0.0001 \\
\hline \multicolumn{2}{|l|}{ Irri. $\times$ wet } & & 0.013 & 0.705 \\
\hline \multicolumn{2}{|l|}{ Gel $\times$ wet } & & 0.654 & 0.154 \\
\hline \multicolumn{2}{|c|}{ Irri. $\times$ gel $\times$ wet } & & 0.421 & 0.641 \\
\hline
\end{tabular}

weekly. Trickle emitter applications of $75 \mathrm{ml} \mathrm{H}_{2} \mathrm{O}$ at a rate of $3 \mathrm{ml} \cdot \mathrm{s}^{-1}$ with a precision manual dispensing pump were made on the same occasions as overhead sprinkler applications. Pots in flood-and-drain trays (Elliott, 1992) were irrigated twice daily. Trays were flooded to a depth of $1 \mathrm{~cm}$ for $30 \mathrm{~min}$ at each irrigation. The capillary mat was flooded for $1 \mathrm{~min}$ every hour using a modified form of the flood-and-drain tray. Subirrigation systems were set up in an incubator maintained at $20 \pm 2 \mathrm{C}$, and pots irrigated by sprinkler or trickle emitter were irrigated with water at $20 \mathrm{C}$ and kept in the incubator between irrigations. Relative humidity in the incubator was not controlled, but was measured occasionally, within the range of $60 \%$ to $80 \%$.

Pots were weighed three to four times weekly until no weight increases were observed. EWHC was calculated as net water retention at the termination of the irrigation treatments. CCAP was subsequently measured by saturating the medium by immersion in water to the height of the top of the medium for 24 h, followed by $24 \mathrm{~h}$ drainage (White and Mastalerz, 1966). Data were analyzed using the SAS general linear model procedure (SAS, 1988). Each base medium (rockwool-peat combination) was analyzed as a separate experiment with four irrigation treatments, four gel-wetting agent combinations, and three pots per irrigation-gel-wetting agent treatment, for a total of 48 pots per experiment.

\section{Results}

Most water uptake occurred within 7 days; however, EWHC was attained only after prolonged irrigation. Regression analysis of data obtained with the 1 peat : 1 hydrophobic rockwool medium (Fig. 1) after 15 days of irrigation (>1O irrigations for

\begin{tabular}{|c|c|c|c|c|}
\hline \multirow[b]{2}{*}{ Irrigation } & \multirow[b]{2}{*}{ Gel } & \multirow{2}{*}{$\begin{array}{c}\text { Wetting } \\
\text { agent }\end{array}$} & \multicolumn{2}{|c|}{$\begin{array}{l}\text { Water retention } \\
\quad\left(\mathrm{g} \mathrm{H}_{2} \mathrm{O} / \mathrm{pot}\right)\end{array}$} \\
\hline & & & CCAP & EWHC \\
\hline \multirow[t]{4}{*}{ Overhead sprinkler } & - & - & $284 \pm 12.3$ & $235 \pm 11.1$ \\
\hline & - & + & $277 \pm 1.4$ & $237 \pm 3.1$ \\
\hline & + & - & $352 \pm 10.2$ & $326 \pm 10.5$ \\
\hline & + & + & $351 \pm 1.9$ & $335 \pm 3.8$ \\
\hline \multirow[t]{4}{*}{ Trickle emitter } & - & - & $276 \pm 0.8$ & $242 \pm 2.1$ \\
\hline & - & + & $269 \pm 2.1$ & $241 \pm 4.6$ \\
\hline & + & - & $340 \pm 1.9$ & $297 \pm 45.0$ \\
\hline & + & + & $337 \pm 8.6$ & $323 \pm 6.7$ \\
\hline \multirow[t]{4}{*}{ Flood and drain } & - & - & $290 \pm 3.7$ & $221 \pm 2.5$ \\
\hline & - & + & $278 \pm 3.1$ & $222 \pm 5.5$ \\
\hline & + & - & $343 \pm 3.1$ & $263 \pm 4.5$ \\
\hline & + & + & $324 \pm 2.0$ & $264 \pm 3.1$ \\
\hline \multirow[t]{4}{*}{ Capillary mat } & - & - & $291 \pm 1.8$ & $177 \pm 4.0$ \\
\hline & - & + & $275 \pm 1.1$ & $181 \pm 2.3$ \\
\hline & + & - & $345 \pm 4.7$ & $220 \pm 5.5$ \\
\hline & + & - & $329 \pm 7.4$ & $233 \pm 9.0$ \\
\hline \multicolumn{5}{|l|}{ Analysis of variance } \\
\hline \multicolumn{3}{|l|}{ Source } & \multicolumn{2}{|c|}{$P>\mathrm{F}$} \\
\hline \multicolumn{2}{|l|}{ Irrigation (Irri.) } & & 0.1219 & 0.0004 \\
\hline \multicolumn{2}{|l|}{$\mathrm{Gel}$} & & 0.0001 & 0.0001 \\
\hline \multicolumn{2}{|l|}{ Wetting agent } & & 0.860 & 0.011 \\
\hline \multicolumn{2}{|l|}{ Irri. $\times$ gel } & & 0.0001 & 0.0001 \\
\hline \multicolumn{2}{|l|}{ Irri. $\times$ wet } & & 0.236 & 0.453 \\
\hline \multicolumn{2}{|l|}{ Gel $\times$ wet } & & 0.027 & 0.354 \\
\hline \multicolumn{2}{|c|}{ Irri. $\times$ gel $\times$ wet } & & 0.576 & 0.482 \\
\hline
\end{tabular}

trickle emitter and overhead sprinkler irrigation and >30 irrigations for flood-and-drain) indicated that small but significant $(\mathrm{P}<0.05)$ linear weight gains occurred up to 32 days in nine of the 16 treatments. Weight gain was not significant in the medium with wetting agent and without gel for all irrigation systems, but no consistent effects were observed for any other media treatments.

EWHC was higher with sprinkler or trickle emitter than with flood-and-drain or capillary mat in all media (Tables 1-4). CCAP was slightly lower for sprinkler or trickle irrigation than for the other two methods in 2 peat : 1 hydrophilic rockwool (Table 1), 1 peat : 1 hydrophilic rockwool (Table 3 ), and 1 peat : 1 hydrophobic rockwool (Table 4) media. The hydrophilic gel increased EWHC and CCAP with all media and irrigation systems (Tables 1-4). Over all irrigation, media, and wetting agent treatments, the hydrophilic gel increased EWHC 33\% and CCAP $23 \%$. The wetting agent increased EWHC slightly in media containing hydrophobic rockwool (Tables 2 and 4). Media without the hydrophilic gel lost more volume due to slumping than gel-amended media (Fig. 2).

Significant interactions of gel and wetting agent occurred for CCAP in 2 peat : 1 hydrophilic rockwool (Table 1), 2 peat : 1 hydrophobic rockwool (Table 2), and 1 peat : 1 hydrophobic rockwool (Table 4). In 2 peat : 1 hydrophilic rockwool, CCAP was lower in the medium containing both gel and wetting agent than in the medium containing only gel. In the other media, CCAP was higher in media containing both wetting agent and gel than in media containing only gel. An interaction of gel and wetting agent for EWHC occurred in the 1 peat : 1 hydrophobic rockwool (Table 4), in which case EWHC of medium containing 
Table 3. CCAP and EWHC in a medium composed of 1 sphagnum peat : 1 hydrophilic, granulated, medium-sized rockwool $(\mathrm{v} / \mathrm{v})$, amended as indicated with a hydrophilic gel or a granulated wetting agent. Each datum is the mean and SD of three observations.

\begin{tabular}{|c|c|c|c|c|}
\hline \multirow[b]{2}{*}{ Irrigation } & \multirow[b]{2}{*}{ Gel } & \multirow{2}{*}{$\begin{array}{c}\text { Wetting } \\
\text { agent }\end{array}$} & \multicolumn{2}{|c|}{$\begin{array}{c}\text { Water retention } \\
\left(\mathrm{g} \mathrm{H}_{2} \mathrm{O} / \text { pot }\right)\end{array}$} \\
\hline & & & CCAP & EWHC \\
\hline \multirow[t]{4}{*}{ Overhead sprinkler } & - & - & $274 \pm 5.9$ & $251 \pm 7.5$ \\
\hline & - & + & $296 \pm 2.8$ & $287 \pm 4.8$ \\
\hline & + & - & $354 \pm 8.6$ & $351 \pm 11.6$ \\
\hline & + & + & $353 \pm 10.0$ & $345 \pm 16.2$ \\
\hline \multirow[t]{4}{*}{ Trickle emitter } & - & - & $292 \pm 5.7$ & $287 \pm 3.8$ \\
\hline & - & + & $284 \pm 2.6$ & $278 \pm 3.3$ \\
\hline & + & - & $352 \pm 10.1$ & $352 \pm 11.9$ \\
\hline & + & + & $334 \pm 4.7$ & $333 \pm 5.5$ \\
\hline \multirow[t]{4}{*}{ Flood and drain } & - & - & $312 \pm 4.1$ & $218 \pm 21.0$ \\
\hline & - & + & $299 \pm 0.8$ & $244 \pm 1.1$ \\
\hline & + & - & $358 \pm 8.7$ & $268 \pm 16.6$ \\
\hline & + & + & $350 \pm 11.5$ & $293 \pm 11.4$ \\
\hline \multirow[t]{4}{*}{ Capillary mat } & - & - & $286 \pm 14.0$ & $146 \pm 9.1$ \\
\hline & - & + & $303 \pm 4.9$ & $204 \pm 10.5$ \\
\hline & + & - & $356 \pm 2.7$ & $209 \pm 8.8$ \\
\hline & + & + & $350 \pm 5.1$ & $256 \pm 7.7$ \\
\hline \multicolumn{5}{|l|}{ Anaysis of variance } \\
\hline \multicolumn{2}{|l|}{ Source } & & \multicolumn{2}{|c|}{$P>\mathrm{F}$} \\
\hline Irrigation (Irri.) & & & 0.0004 & 0.0001 \\
\hline $\mathrm{Gel}$ & & & 0.0001 & 0.0001 \\
\hline Wetting agent & & & 0.410 & 0.0001 \\
\hline Irri. $\times$ gel & & & 0.019 & 0.017 \\
\hline Irri. $\times$ wet & & & 0.0009 & 0.0001 \\
\hline Gel $\times$ wet & & & 0.005 & 0.019 \\
\hline
\end{tabular}

gel alone was slightly higher than medium containing both gel and wetting agent.

A significant interaction of irrigation method, wetting agent, and gel was obtained for EWHC in the 1 peat : 1 hydrophobic rockwool medium (Table 4). Wetting agent increased EWHC in gel-amended medium irrigated by sprinkler or trickle emitter, but decreased it in gel-amended medium irrigated by flood-anddrain or capillary mat.

Over all media, irrigation, gel, and wetting agent treatments, CCAP was $24 \%$ higher than EWHC. EWHC was reasonably well correlated with CCAP for overhead sprinkler and trickle emitter irrigation (overhead irrigation) (Fig. 3). Lower, but still significant, correlation was obtained for flood-and-drain and capillary mat irrigation (subirrigation). In both cases, the slope coefficient for regression of EWHC on CCAP was near unity. Intercepts were negative and about three times higher for subirrigation than overhead irrigation.

\section{Discussion}

As most imbibition occurred within the first week and effects of wetting agent and gel were already evident at that time, it follows that the initial rate of imbibition was increased by incorporation of these materials. The wetting agent tended to accelerate imbibition even when final retention was similar (Fig. 1). In the 1 peat : 1 hydrophobic rockwool medium, retention of water following the first wetting and at the first observation following the initiation of irrigation treatments showed the same trends as those for EWHC (Fig. 1 and Table 4).

Higher EWHC in overhead than subirrigation treatments indicates a greater ability of media to retain water passing
Table 4. CCAP and EWHC in a medium composed of 1 sphagnum peat : 1 hydrophobic granulated, medium-sized rockwool (v/v), amended as indicated with a hydrophilic gel or a granulated wetting agent. Each datum is the mean and sD of three observations.

\begin{tabular}{|c|c|c|c|c|c|}
\hline \multirow[b]{2}{*}{ Irrigation } & \multirow[b]{2}{*}{ Gel } & \multirow{2}{*}{$\begin{array}{c}\text { Wetting } \\
\text { agent }\end{array}$} & \multicolumn{3}{|c|}{$\begin{array}{c}\text { Water retention } \\
\left(\mathrm{g} \mathrm{H}_{2} \mathrm{O} / \text { pot }\right)\end{array}$} \\
\hline & & & $\mathrm{CCA}$ & & EWHC \\
\hline \multirow[t]{4}{*}{ Overhead sprinkler } & - & - & $215 \pm$ & 6.4 & $190 \pm 4.7$ \\
\hline & - & + & $211 \pm$ & 3.6 & $193 \pm 2.5$ \\
\hline & + & - & $287 \pm$ & 5.7 & $277 \pm 7.9$ \\
\hline & + & + & $299 \pm$ & 6.6 & $285 \pm 2.6$ \\
\hline \multirow[t]{4}{*}{ Trickle emitter } & - & - & $200 \pm$ & 5.2 & $182 \pm 6.1$ \\
\hline & - & + & $204 \pm$ & 3.2 & $190 \pm 1.2$ \\
\hline & + & - & $274 \pm$ & 4.6 & $265 \pm 5.5$ \\
\hline & + & + & $282 \pm$ & 4.7 & $271 \pm 6.6$ \\
\hline \multirow[t]{4}{*}{ Flood and drain } & - & - & $244 \pm$ & 32.7 & $129 \pm 3.8$ \\
\hline & - & + & $222 \pm$ & 7.0 & $156 \pm 3.1$ \\
\hline & + & - & $281 \pm$ & 5.9 & $211 \pm 9.1$ \\
\hline & + & + & $295 \pm$ & 8.2 & $192 \pm 6.6$ \\
\hline \multirow[t]{4}{*}{ Capillary mat } & - & - & $229 \pm$ & 4.0 & $93 \pm 5.5$ \\
\hline & - & + & $231 \pm$ & 4.6 & $123 \pm 3.6$ \\
\hline & + & - & $283 \pm$ & 8.9 & $165 \pm 2.5$ \\
\hline & + & + & $289 \pm$ & 9.6 & $137 \pm 2.1$ \\
\hline \multicolumn{6}{|l|}{ Analysis of variance } \\
\hline \multicolumn{3}{|l|}{ Source } & \multicolumn{3}{|c|}{$P>\mathrm{F}$} \\
\hline \multicolumn{2}{|l|}{ Irrigation (Irri.) } & & 0.00 & & 0.0001 \\
\hline \multicolumn{2}{|l|}{ Gel } & & 0.00 & & 0.0001 \\
\hline \multicolumn{2}{|l|}{ Wetting agent } & & 0.42 & & 0.008 \\
\hline \multicolumn{2}{|l|}{ Irri. $\times$ gel } & & 0.00 & & 0.0001 \\
\hline \multicolumn{2}{|l|}{ Irri. $\times$ wet } & & 0.61 & & 0.533 \\
\hline \multicolumn{2}{|l|}{ Gel $\times$ wet } & & 0.01 & & 0.0001 \\
\hline \multicolumn{2}{|c|}{ Irri. $\times$ gel $\times$ wet } & & 0.19 & & 0.0001 \\
\hline
\end{tabular}

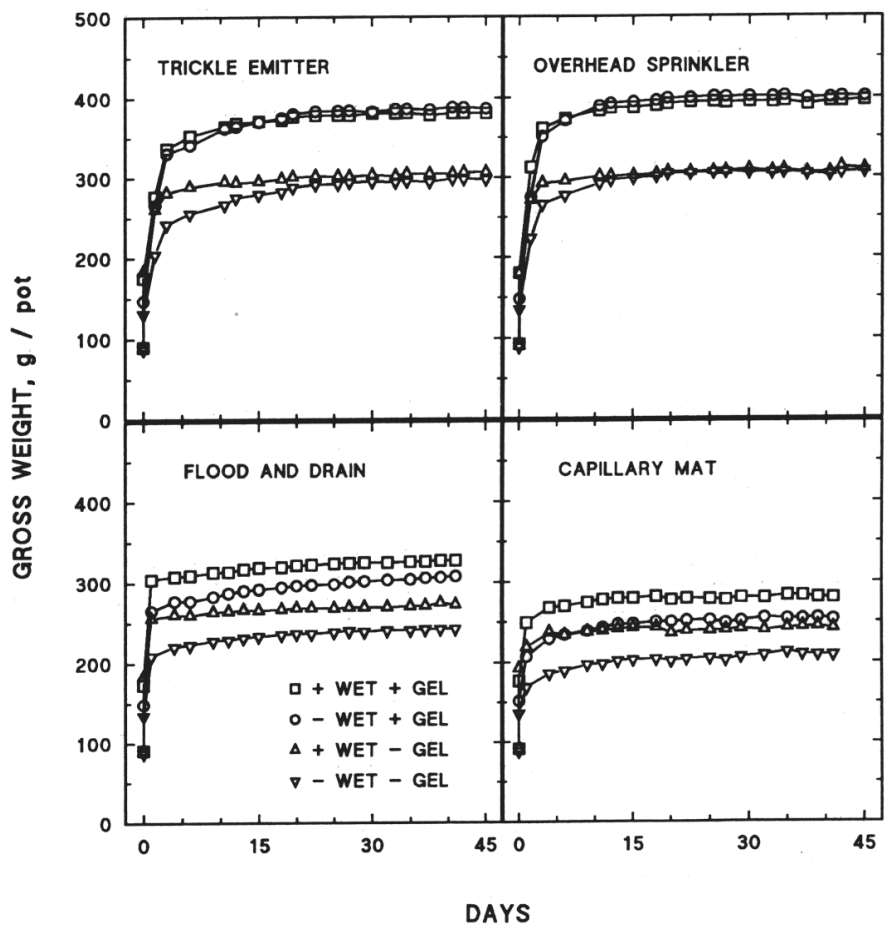

Fig. 1. Time course of water imbibition by media composed of 1 sphagnum peat : 1 hydrophobic rockwool (v/v) amended with wetting agent or hydrophilic gel and irrigated as indicated. 


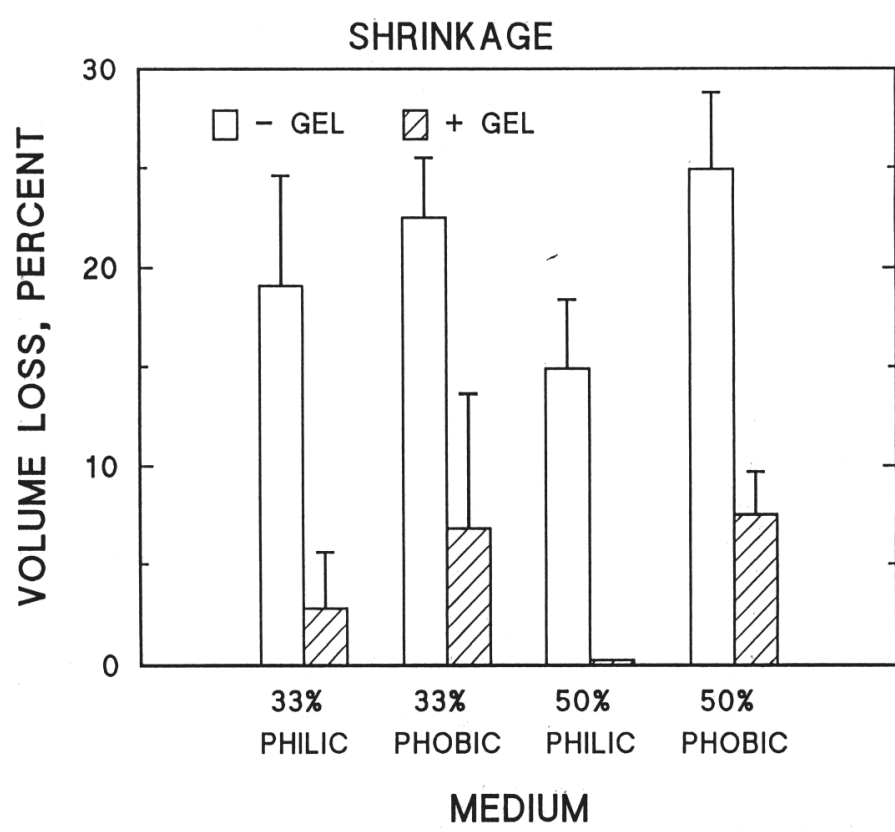

Fig. 2. Effect of hydrophilic gel on volume reduction (shrinkage) in sphagnum peat hydrophiiic (philic) and hydrophobic (phobic) rockwool media. Data are averaged over all irrigation treatments. Error bars show $\mathrm{SD}, \mathrm{n}=24$. Effect of gel on shrinkage was highly significant $(\mathrm{P}<0.001)$ for all media. Percentages refer to proportion in medium.

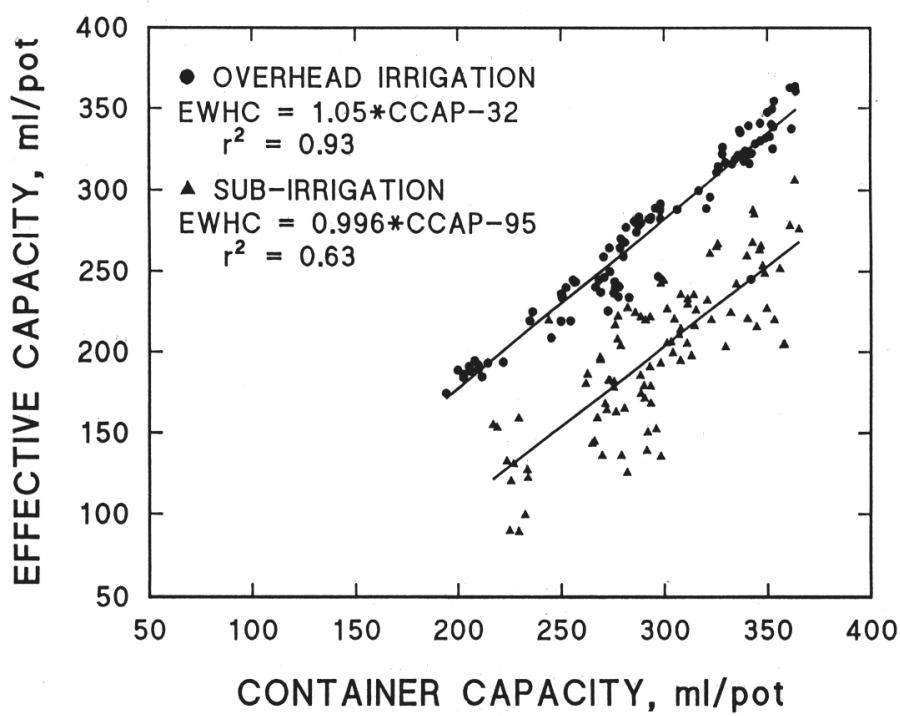

Fig. 3. Correlation of CCAP and EWHC in peat-rockwool media. Overhead irrigation includes trickle emitter and overhead sprinkler treatments. Subirrigation includes capillary mat and flood-and-drain treatments. Regression coefficients for slope and intercept are statistically significant $(\mathrm{P}<0.05)$, and separate regressions for overhead and subirrigation account for significantly more variability than a single regression.

through than to absorb water by capillary rise. Sprinkler irrigation, which distributed water over the entire surface of the medium, generally allowed more retention than trickle irrigation, which applied water to a relatively small area. Channeling of water through large pores in the medium and low rates of lateral movement were probably responsible for lower retention with trickle irrigation. Decreased CCAP in overhead irrigation treatments compared to subirrigation was probably due to decreased porosity as the result of increased slumping in overhead-irrigated media.

Although interactions of the hydrophilic gel and wetting agent were observed in some instances, the responses were not consistent among media and irrigation treatments. In the 1 peat : 1 hydrophobic rockwool medium irrigated by overhead sprinkler or trickle emitter, EWHC was higher with the combination of wetting agent and gel than with gel alone. The increase was essentially additive. However, in the same medium irrigated by flood-and-drain and capillary mat, EWHC was lower with the combination of gel and wetting agent than with gel alone. A synergistic interaction of hydrophilic gel and wetting agent was observed for EWHC in the 2 peat : 1 hydrophilic rockwool medium irrigated by trickle emitter (Table 1). Gel alone increased EWHC 23\% compared to the unamended control, while wetting agent alone had no effect; The combination of gel and wetting increased EWHC 33\%. Similar results were obtained with the same medium irrigated by capillary mat or overhead sprinkler. However, the combination of wetting agent and gel was no different from gel alone in the flood-and-drain irrigation treatment. Synergistic interactions of hydrophilic gel and wetting agent have previously been observed with other soilless potting media. In peat-vermiculite-perlite and peat-pinebarkperlite media irrigated by flood-and-drain, wetting agent alone increased EWHC while gel had no effect, whereas the combination of gel and wetting agent yielded higher EWHC than wetting agent alone (Blodgett and Elliott, unpublished data).

The term "container capacity" is sometimes used as equivalent to "effective water-holding capacity" (Jenkins and Jarrell, 1989) as defined in this report. However, the original use of the term "container capacity" (White and Mastalerz, 1966) clearly involves an operational definition in which media are saturated and allowed to drain freely in a defined container. The term "effective water-holding capacity" advanced in this report also involves an operational definition and depends on characteristics of the medium, container, and irrigation system.

CCAP was higher than EWHC. Regression of EWHC on CCAP revealed that reasonably useful correlations were obtained for subirrigation and top irrigation methods. In practice, empirical correlation of CCAP and EWHC is required, since factors that increase EWHC, such as use of a wetting agent or overhead irrigation, may decrease CCAP. Models that predict water retention under equilibrium conditions may not accurately predict actual water retention.

Further research will be required to determine if similar relationships between EWHC and CCAP can be obtained in other containers and with other media. EWHC in potting media is expected to be rarely, if ever, equal to CCAP, because the medium in a pot is generally not completely saturated during irrigation.

\section{Literature Cited}

Airhart, D.L., N.J. Natarella, and F.A. Pokorny. 1978. Influence of initial moisture content on wettability of a milled pine bark medium. HortScience 13:432-434.

Bilderbeck, T.E. 1987. Moisture extender and wetting agent effects on two drought-sensitive nursery crops. HortScience 22:73. (Abstr.)

Bowman, D.C., R.Y. Evans, and J.L. Paul. 1990. Fertilizer salts reduce hydration of polyacrylamide gels and affect physical properties of gel-amended container media. J. Amer. Soc. Hort. Sci. 115:382-386.

Elliott, G.C. 1992. A pulsed subirrigation system for small plots. HortScience 27:71-72.

Fonteno, W.C. and P.V. Nelson. 1990. Physical properties of and plant 
responses to rockwool-amended media. J. Amer. Soc. Hort. Sci. 115:375-381.

Jenkins, J.R. and W.M. Jarrell. 1989. Predicting physical and chemical properties of container mixtures. HortScience 24:292-295.

Milks, R.R., W.C. Fonteno, and R.A. Larson. 1989a. Hydrology of horticultural substrates: I. Mathematical models for moisture characteristics of horticultural container media. J. Amer. Soc. Hort. Sci. 114:48-52.

Milks, R.R., W.C. Fonteno, and R.A. Larson. 1989b. Hydrology of horticultural substrates: II. Predicting physical properties of media in containers. J. Amer. Soc. Hort. Sci. 114:53-56.

Milks, R.R., W.C. Fonteno, and R.A. Larson. 1989c. Hydrology of horticultural substrates: III. Predicting air and water content of limited-volume plug cells. J. Amer. Soc. Hort. Sci. 114:57-61.

Nelson, P.V. 1991. Greenhouse operations and management. 4th ed. Reston Publishing Co., Reston, Va.

SAS Institute. 1988. SAS/STAT Users guide, release 6.03 edition. SAS Institute, Inc., Cary, N.C.

Wang, Y-T. and C.A. Boogher. 1987. Effect of a medium-incorporated hydrogel on plant growth and water use of two foliage species. J. Environ. Hort. 5:125-127.

White, J.W. and J.W. Mastalerz. 1966. Soil moisture as related to container capacity. Proc. Amer. Soc. Hort. Sci. 89:758-765. 